\title{
Behaviors related to Quilombola women's health: a social representations study
}

\author{
Comportamentos relacionados com a saúde de mulheres quilombolas: um estudo de representações sociais
} Comportamientos de mujeres quilombolas referentes a la salud: un estudio de representaciones sociales

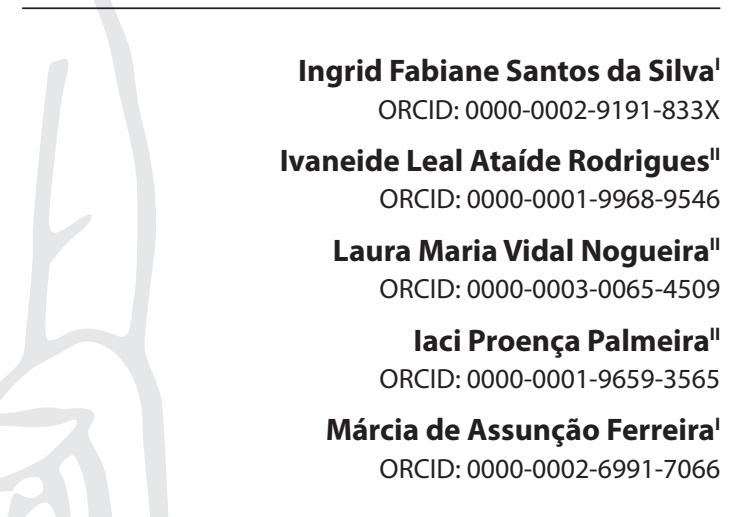

'Universidade Federal do Rio de Janeiro. Rio de Janeiro, Rio de Janeiro, Brazil.

"Universidade do Estado do Pará. Belém ,Pará, Brazil.

How to cite this article: Silva IFS, Rodrigues ILA, Nogueira LMV, Palmeira IP, Ferreira MA. Behaviors related to Quilombola women's health: a social representations study. Rev Bras Enferm. 2020;73(Suppl 4):e20190427 doi: http://dx.doi.org/10.1590/0034-7167-2019-0427

Corresponding author: Ingrid Fabiane Santos da Silva E-mail: ingridenfermeir@gmail.com

EDITOR IN CHIEF: Dulce Barbosa ASSOCIATE EDITOR: Antonio José de Almeida Filho

Submission: 10-16-2019

Approval: 04-07-2020

\begin{abstract}
Objective: To Identify Quilombola women's social representations about health care and to characterize practices performed by them. Method: a descriptive, qualitative study, applying the Social Representations Theory, conducted with 30 women from a Quilombola community in the Brazilian Amazon. Individual interviews and thematic content analysis were carried out. Results: Health care practices are related to the home, people, families, and environment, indicating a Quilombola women's extended understanding about health care. In the first instance, natural resources derived from traditional knowledge and use of herbs are applied, in the second instance, the official health system, with the mother-woman being the main caregiver of the family. Final Considerations: the mother enables a health care in the family daily life, and she is the main way of access health professionals have to enter the Quilombola community and provide proper care from the official health system to the group. Descriptors: African Continental Ancestry Group; Women; Health behavior; Psychology, Social; Nursing.
\end{abstract}

\section{RESUMO}

Objetivo: Identificar as representações sociais de mulheres quilombolas sobre o cuidado em saúde e caracterizar as práticas por elas realizadas. Método: Estudo descritivo, qualitativo, com aplicação da Teoria das Representações sociais, realizado com 30 mulheres de uma comunidade quilombola da Amazônia Brasileira. Realizaram-se entrevistas individuais e análise temática de conteúdo. Resultados: As práticas de cuidado à saúde se relacionam à casa, às pessoas, às famílias e ao meio ambiente, indicando uma compreensão ampliada das muIheres quilombolas sobre o cuidado à saúde. Em primeira instância, aplicam-se os recursos naturais, advindos de saberes tradicionais e uso de ervas, em segunda instância, o sistema oficial de saúde, sendo a mulher-mãe a principal cuidadora da família. Considerações Finais: A mãe viabiliza o cuidado à saúde no cotidiano familiar e indica ser a principal via de acesso dos profissionais de saúde para adentrar a comunidade quilombola e fazer chegar ao grupo os cuidados próprios do sistema oficial de saúde.

Descritores: Grupo com Ancestrais do Continente Africano; Mulheres; Comportamentos Relacionados com a Saúde; Psicologia Social; Enfermagem.

\section{RESUMEN}

Objetivo: Identificar las representaciones sociales sobre el cuidado de la salud de mujeres quilombolas y especificar las prácticas que realizan. Método: Se trata de un estudio descriptivo y cualitativo, en el que se aplicó la Teoría de las Representaciones Sociales con análisis temático de contenido, llevado a cabo mediante entrevistas individuales entre 30 mujeres de una comunidad quilombola del Amazonas brasileño. Resultados: Las prácticas sanitarias estaban relacionadas con el hogar, las personas, las familias y el medio ambiente, lo que indica que dichas mujeres tienen una comprensión amplia sobre el cuidado. Primero utilizan los recursos naturales derivados de los conocimientos tradicionales; después, recurren al sistema oficial de salud, siendo la mujer-madre la principal cuidadora de la familia. Consideraciones finales: La madre se encarga del cuidado de la salud familiar y es la principal vía de acceso para que los profesionales sanitarios entren en la comunidad quilombola y hagan llegar al grupo la atención del sistema oficial de salud.

Descriptores: Grupo con Ancestros del Continente Africano; Mujeres; Comportamientos Relacionados a la Salud; Psicología Social; Enfermería. 


\section{INTRODUCTION}

Health care has been the object of several studies in the Health Sciences field, especially in Nursing, an area in which that notion has a fundamental character. The word cuidado (care) derived from Latin coera and cogitare - cogitates which means healing, thinking, showing interest in something, concern. Therefore, care is revealed as attentiveness, concern, commitment, an attitude of importance, a way of being and connecting with others and with the world around us, because through that the individual feels fulfilled and relates, that is, care is an existential way of recognizing and identifying with the other and the world ${ }^{(1)}$. It is worth mentioning that there is a strong link between care and the female gender, the result of a historical and social construction in which women are given the central role in relation to care, especially in the family environment, in which they are still responsible for the care of children and the home $e^{(2-3)}$.

The women's caretaking acquired different connotations and characteristics, as to the way of thinking and practicing it. Among these, health care based on traditional knowledge, which handles plants, herbs, fruits, roots, and seeds, stands out, and has been connected to women since the development of agricultural practice $^{(4)}$. This connection made it possible to learn and improve practices based on traditional knowledge that accompany until today the health care dynamics of traditional peoples, mainly indigenous populations and those of African origin in Brazil.

Regarding African people and their descendants (Quilombolas, people from terreiros (meeting places), riparian, among others.), the way in which they take care of their health has particularities and singularities, which are linked to the way their political, social, cultural, religious, and identity spheres are structured and organized. Such ways allowed the transferability of different social practices related to the environment, territory, and religiosity.

Quilombos are known in Brazilian history for their trajectory of resistance, and fight against slavery and the slave system that placed black people in a condition of subjugation. Currently, quilombos are considered spaces of resistance that provide the rescue of the history and culture of African people and their descendants, through the strengthening of culture and solidarity, where black people/Quilombolas are subjects of their own history ${ }^{(5)}$.

The health care practices of these groups are based on traditional medicine, which can be understood as a set of knowledge, beliefs, and superstitions that are structured in a daily practice to face the processes of illness, having the unique characteristic of being shared orally from one generation to another. This type of care involves values, customs, traditions, and beliefs, derived from particular cultural experiences of a certain group, has a cultural bias and subsidizes the community for the maintenance of well-being, coping with diseases, disabilities and even death ${ }^{(6-7)}$.

In the literature, popular and traditional health practices are recognized by various nomenclatures, such as unofficial practices, traditional medicine, alternative medicine, and integrative and complementary practices. The authors define these practices as any form of healing other than biomedical, in addition to covering the definition for blessing practices and those of a religious nature, that is, practices which originate in popular culture ${ }^{(8)}$.

In the Quilombola populations context, women are also the ones who perpetuate health care practices ${ }^{(9)}$, and in most communities, there is the use of herbs, medicinal plants, prayers and blessings that are spread by popular tradition by healers, herbalists and religious authorities ("Mothers-of-Saint", lalorixás, pastors, among others), becoming the main resource against illness and health problems, given the limited access to public health services by the Quilombola population, which is mostly located in rural areas.

It is understood that traditional health care practices are culturally relevant in this group, since the use of these practices is a striking element in their context, also because it is understandable that traditional knowledge represents a way of thinking about health care, and the popular practices are the constitution of this object in the group's everyday life since they are put into daily practice.

Due to its cultural relevance, health care in these communities can be understood from social representations, which express a type of particular knowledge, of common sense, with practical function, which are related to people's experience, being built and shared in society or groups ${ }^{(10)}$.

A literature review highlights some of the vulnerabilities of the Quilombola population health conditions, such as difficulty in accessing goods and services, a predominance of chronic diseases, weight gain, and specific and curativistic care ${ }^{(11)}$. In addition to that, the authors draw attention to the need for the improvement of qualitative research ${ }^{(11)}$. It is also observed that in a reflection on the difficulties in defending the rights of access to health care in Quilombolas, the authors emphasize the importance of investigating the representations of the world that interfere in health practices that, therefore, are linked to the everyday life and the relationships between them and the environment that surrounds them. Furthermore, they emphasize that knowledge and respect for health in communities often do not meet the paradigms of Western medicine, but they have their own efficacy ${ }^{(12)}$.

The generation of knowledge about the Quilombola women's wisdom and their care practices can support debates about health care, especially in health training courses, where the topic is still neglected in terms of population health ${ }^{(13)}$, and thus, contribute to the nursing care practice since the training aims to prepare nurses to meet the needs of all population groups.

Therefore, research that explores subjectivities, knowledge, and practices, such as studies on the representations of health care, especially in the Quilombola groups' context, are relevant because they bring out the particularities of minority groups health care that constantly have little visibility either for nursing or for other health professions.

\section{OBJECTIVE}

To identify Quilombola women's social representations about health care and to characterize practices performed by them.

\section{METHOD}

\section{Ethical Aspects}

The research complied with Resolution CNS 466/2012, obtained institutional authorization from the Municipal Health Secretariat of Ananindeua-Pará and the Association of Quilombola Residents and Producers of Abacatal/Aurá - AMPQUA. It was approved by 
the Research Ethics Committee of the State University of Pará. The participants were identified with alphanumeric code: the letter $M$, for women, followed by the order number of the interviews.

\section{Type of Study}

A descriptive study with a qualitative approach, based on the consolidated criteria for reporting qualitative studies - COREQ ${ }^{(14)}$, applying the Theory of Social Representations (TSR) in its procedural aspect. Social representations aim to build a common reality to individuals in a given social group, in addition to mediating social relations of the macro (society) and micro (individual) spheres, such as conducts, communications, identities, among others ${ }^{(15)}$. They allow a relationship of symbolization and interpretation with the represented object, in this case, health care, attributing meanings and analogies that are particular to those who (re)signify it.

The construction processes of social representations are objectification and anchoring. Anchoring seeks to make a certain fact (or object, or word, or any other situation), which at first seems strange and different, into something familiar, closer to its reality and experience, that is, something common to the individual and his collectivity. It allows the classification of the object, its (re)naming, as well as establishing its value based on norms and precepts of the group that represents $i^{(10)}$. Objectification materializes the representations through an image/symbol provided by the previous cognitive process as if it were the transference from the psychic world to the physical, real world ${ }^{(10)}$. In this sense, objectification enables the materialization of any and all objects, which are relationships, ideas, words, among others.

\section{Setting}

The study was conducted at the Abacatal/Aurá Quilombola community, located in the city of Ananindeua, metropolitan region of Belém - Pará, situated approximately eight kilometers from the administrative center of Ananindeua.

\section{Participants}

A total of 30 Quilombola women who experience health care participated, which represents $48.38 \%$ of the 62 women over 18 who live in the community. The number of participants was defined when the data were considered empirically sufficient to meet the research objectives, which, according to a consensus in the scientific literature for qualitative research, occurs between 20 to 30 interviews ${ }^{(16-17)}$.

The inclusion criteria were: adult women, aged over 18 years old, living in the community of Abacatal/Aurá and who were descendants of the three families that originated the community: Rosa, Costa, and Barbosa, the so-called heirs. Those that, despite meeting the inclusion criteria, were not located after three attempts during the data collection period were excluded.

\section{Data collection, organization, and analysis}

Individual interviews were carried out using a semi-structured script whose questions addressed health care practices and the motivations for carrying them out, as well as sociodemographic data, such as religion, family constitution, education, and income, to establish the conditions on the production of social representations ${ }^{(18)}$. Prior contact was made with the community in March 2017, based on a health action promoted by the Ananindeua Health Department (SESAU). At that moment, it was possible to contact the community leader and establish an initial conversation about the research project and interest to run it in the community.

The participants' approach was mediated by the leader who previously indicated the families and the heir women through a nominal list. Thus, she collaborated as a key informant, who in research situations, can help researchers by providing important and accurate information about a certain group, functioning as a link between them and the researchers ${ }^{(19)}$.

The interviews were conducted on the weekends from November/2017 to January/2018, moments in which the author was welcomed into the community, staying at the homes and had the opportunity to share the women's routine. Thus, most of the interviews were conducted at the participants' homes. Data collection ended when the empirical framework of the research was outlined, and in the pre-analysis, the potential for meeting the objective was identified ${ }^{(16-15)}$.

For the thematic content analysis, three stages were followed: pre-analysis, material exploration, and analysis of results ${ }^{(20)}$. Initially, the interviews were transcribed to constitute the corpus of analysis that was subjected to careful reading. In the phases of exploration and analysis of the material, the analytical tables were organized, constituted by the questions of the instrument and the units of register extracted from the statements of each participant. In a horizontal analysis of these tables, the content of the responses of all participants was mapped together for each question asked, identifying common themes. In vertical analysis, the themes in occurrence and co-occurrence were identified in the individual statements to the set of questions. Altogether, 390 registration units were registered, highlighting themes, expressions, and metaphors, in order to identify the contents that made sense in the characterization of women's practices on the object.

\section{RESULTS}

It was identified that, mostly, in 23 statements (76.66\%), the care practiced by Quilombola women is general hygiene and cleaning of the body, of the house or even of the entire community, and also eating habits.

In the morning I take care of them [children], I do housework, when I am not working I take care of them [...] of their food, of their bath. (M4)

I like my things very clean and the water I like [...] our water is not treated, but whenever I can I add chlorine, if I can boil it, I do it. I am careful with things because of the bacteria thing now, [...]. The garbage, to pick up all the garbage and put it in the right place to burn the garbage so that it cannot be destroyed out there [...]. I also don't like it when they [trees] are being cut down, to destroy nature, we have to preserve the environment. I have that as a way of care too. (M11)

Oh I do everything. I make lunch, dinner, do the dishes, sweep my yard, weed my yard, I do everything indoors. I fill water, even wash clothes, I do everything inside the house. (M22) 
General care corresponds to people's health conditions, with emphasis on two aspects: preventive care and care aimed at diagnosis with therapeutic views. In the first aspect, the person is healthy, with no signs of illness or changes in health status (healthy/ill), the health care practiced is what aims to maintain a healthy state, with the purpose of preserving health and avoiding illness. In this case, the body and the environment are taken care of in general and basic ways, as it should be, being required personal hygiene care, such as bathing, brushing teeth, cleaning nails, hand washing, walking with protected feet/footwear, especially children, as well as cleaning and organizing the house, the land/mowing area, proper disposal of waste, preservation of nature, and the non-pollution of the environment.

Associated with general care, two other practices related to care during the illness or to avoid it were identified, directed at the changes that occur in the person, such as behavioral changes or clinical manifestations that suggest the illness. The practices carried out in this context of care indicate the use of medicinal plants/herbs, as well as for self-medication by the use of drugs.

An expressive percentage of participants use medicinal plants/ herbs to treat some diseases that are recurrent in the community. Such herbs and medicinal plants applied in health care or even in the treatment of some diseases are configured as a practice for the maintenance and recovery of health. This could be identified in $100 \%$ of the statements, emphasizing that the use of these plants is a constant practice in the absence of health services, or even in the presence of these.

Because when I have a headache, I take a pill for the headache to pass, I calm down a little, I prepare a bush bath to my head [medicinal plants and herbs], I apply ointment, I apply gel on the pain of my knee, on my legs, then I think I'm taking care of myself. (M7)

When it is him [husband] who gets sick, sometimes, I am here beside him I take care of him, I make tea, I try to call the children to take to the doctor, I make homemade tea to give, the one I know how to, right? And I try to take him to the hospital right away, and that's it. (M29)

Then we look for a doctor, like, more when we are really sick, we are not usually at the doctor every month [...]. We end up looking for a second-class doctor, for later, because we first ask for advice here from older people and end up making a homemade medicine, then when it doesn't work we end up looking for the doctor. (M16)

The use of drugs by self-medication (19/63.33\%), the use of health services and the search for health professionals also appeared in the statements as a complement or even continuity of health care.

Such care practices are mentioned related to those who practice them, and about this agent, Quilombola women extolled their mothers as the best representation of the person who cares, for gathering attitudinal attributes necessary for this function.

The image I picture of a caregiver is my mom [...] we have our psychological saying that no one takes better care of us than our mom, nor do I take care of myself as well as my mom would take care of me. (M1)
Ispeak as a mother [...]. It is to observe, it is to perceive, it is to want your loved ones well, so a caregiver is that person who has the vision of everything to be able to be, to be able to observe where it need to be cared for, what needs to be improved, to cure, what needs to cure some things, so a caregiver is a person who has an eagle vision, she has to observe everything to be able to be looking for improvements in certain points. (M25)

I think my mom is an exemplary mom, like a supermom. (M9)

I am the mainstay of my family, and if I don't keep pushing, nothings goes ahead, you know? Everyone stays in one place, because they [children and husband] depend on me for everything. (M8)

In the composition of the supermom figure, women exalt the quality of attention, which is expressed by a metaphor that informs its reach, which is the vision of an eagle and also evokes the support of the family, anchoring itself in the meaning of the mainstay.

In the light of the Quilombola women's social representations, caring requires attributes such as responsibility and commitment to husband, children, other members of their family network and others that may need care. Therefore, the exercise of care requires characteristics and qualities from its agents, and the main ones listed were: responsibility, patience, concern, being attentive, protective, caring, loving. This set of elements and characteristics facing the conception of the person who cares gave rise to an iconic figure, objectified in a person who aggregates all these qualities. This caregiver woman, the mainstay of the home, is translated into a concept idea, symbolically represented as a supermom (Figure 1), whose figure is outlined based on an idealization of behaviors that one must have in order to fulfill the function expected of her.

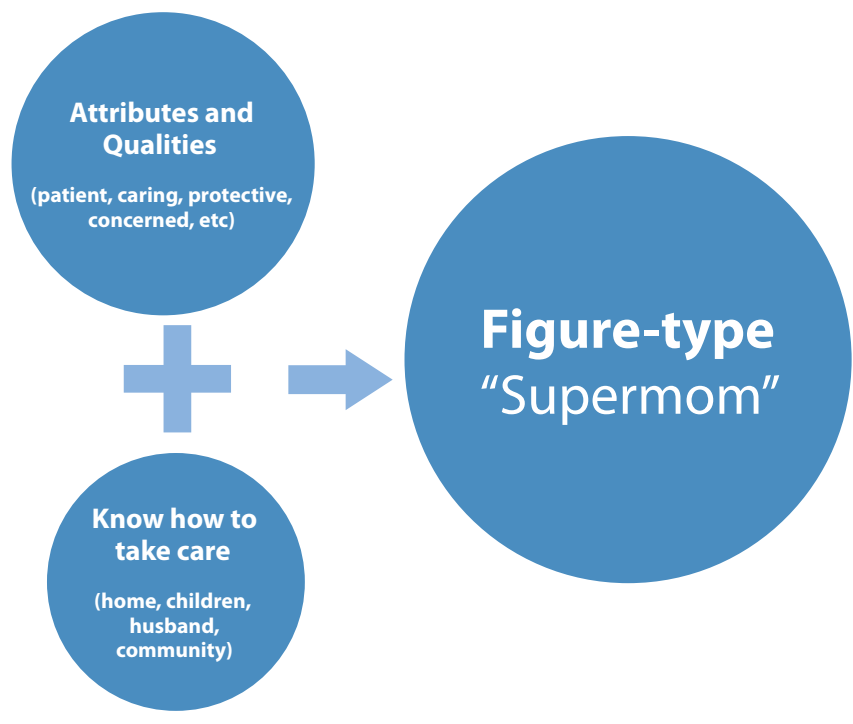

Figure 1 - Caregiver figure-type

The supermom is a figure attentive to everything, being able to solve all the demands directed at her. This attention that embraces everything and everyone around you is signified as an eagle's vision. That is why it is not just any person, it is the mother, and much more than an ordinary mother, who performs her social role just like the others, she needs to be described in 
the superlative, accompanied by the prefix super, objectified in the figure of superheroes who have superpowers and are able to solve the problems of humanity, so this mother/caregiver is in the imagination of women as an unusual person.

\section{DISCUSSION}

In a study on the care of parents and guardians of preschool children $^{(21)}$ in which $79.5 \%$ of respondents were women, health care practices were also represented by bathing, tooth brushing, hand washing, cutting nails and walking wearing shoes. Similar results were found in a study ${ }^{(22)}$ that dealt with the representations of breastfeeding practices for women of three different generations, in which baby care emerged as one of the categories of these representations. In this context, general care practices of hygiene and eating habits were evidenced, as a way of prevention, which reflect the hygienist and curativistic model, typical of the biomedical model. Such results, even though have emerged from studies carried out in contexts and in a population group different from the focus of the research on screen, show that hygienic, body and food care appear as a common concern of the female group, in relation to their families.

Social representations are capable of influencing the person's action in relation to the object ${ }^{(10)}$, in this case it is understood that when conceiving health care as a way to stay healthy, women seek to avoid illness and preserve health through preventive practices. One of these practices is evident in the constant concern shown by them with the quality of the water ingested, as the community is located near a sanitary landfill that serves the metropolitan region of Belém, causing an important environmental impact due to the risk of contamination of groundwater by the penetration into the soil of the manure produced by the decomposition of waste ${ }^{(23)}$.

Thus, the practice of boiling and the addition of purifying solutions, such as hypochlorite in water, are necessary precautions in order to avoid becoming ill, as it is known that some diseases are disseminated through ingestion and contact with contaminated water, and its appearance gains relevance in the absence of basic sanitation services, such as treated water, adequate waste disposal and garbage collection, a relevant concern since Ananindeua has the worst index of basic sanitation in Brazil(24).

In a study carried out on the health profile of the Abacatal/ Aurá community ${ }^{(25)}$ it was found that the main source of water in the community is the artesian well in $55.38 \%$ of households, $66.15 \%$ dump solid and liquid waste in septic tanks and $93.08 \%$ of households incinerate the waste produced, which is similar to results found in other studies ${ }^{(26-29)}$. These conditions are part of the Quilombola populations' scenario and favor the appearance of water-borne diseases, diarrhea, soil-transmitted helminthiasis, taeniasis, among others affecting the population as a whole $\mathrm{e}^{(30)}$.

Another important point is the relationship between the environment and health in the Quilombola context. An intimate relationship with the environment that surrounds them is identified, this is anchored in the idea that the environment influences the health aspects of the population, so taking care of it is part of the context of health care, since its preservation guarantees the balance of nature and people's health, whereas when the environment is unbalanced, health is also affected ${ }^{(31)}$.
The use of plants and medicinal herbs can be associated with the use of drugs or not, for example: taking anti-flu drugs with tea to fight colds, or even introducing them later. In the study on the use of medicines by a Quilombola population in southwest Bahia ${ }^{(32)}$, it was found that the majority of people who self-medicated were women, with $54.3 \%$ of the total respondents, these presented the worst health status, higher number of self-reported diseases and medical consultations in the last 12 months.

It is observed that the official health service is the second option, being activated only when traditional care with natural products, such as herbs, animal fat, etc., does not have the desired effect or when the authority of women in care is not recognized. When necessary, the health professional, especially the doctor, is used to verify the change in the person's health status. The care demanded at this stage refers to the urgent need to go to consultations, perform tests to screen for health changes, as well as a list of preventive actions.

Women are the ones who most use health services in $\operatorname{Brazi}^{(33)}$, and there are several programs implemented in primary care intended for them, especially in health units and the Family Health Strategy - ESF, such as prenatal care, prevention of breast and cervical cancers, reproductive and sexual health, monitoring of children in the Exclusive Breastfeeding Program, and in the Child Growth and Development Program. This provides them with greater contact with health services, and consequently with professionals in the field, whether doctors or nurses, among others, which can promote the medicalization of the female body and incur self-medication ${ }^{(31)}$. Nevertheless, there is an absence of the figure of the nurse, or even of nursing, in the women's speeches with regard to professional health care, indicating the need for an increase in performance, the greater presence or a work of valuing nursing with this population group.

The health care practices performed at home and anchored in popular knowledge move away from the home sphere and common sense and migrate to the sphere of reified knowledge, of prescriptive care guided by the health professional, compatible with the field of science. It is worth noting that, although they belong to different fields of knowledge, common-sense health care practices and those of science appear not in a divergent way for Quilombolas, but strongly interrelated and complementary, being present in the same discourse harmoniously. Therefore, a cognitive polyphasia is identified, expressing the coexistence of different types of rationalities and concepts that are activated when its applications are necessary ${ }^{(33)}$.

The practices derived from common sense knowledge are aimed at homemade teas and are anchored in traditional knowledge, tend to be effective initially as an elementary practice in coping with diseases, as it is part of the reality of those women, is perpetrated in everyday life, passed on from mother to daughter and common to the group. The reified ones, as they are carried out later, after the exhaustion of primary, common and collective possibilities to the community, are carried out in an accessory and auxiliary way, as they depend on several factors such as transportation, financial resources, among others, to be accomplished.

A study carried out with female farmers in the south of the country on the use of medicinal plants in family care showed that the care provided to family members through the use of 
medicinal plants is the first chosen health resource ${ }^{(34)}$. Other studies $^{(7,28,35-36)}$ demonstrated similarities with the results found here with regard to the Quilombola communities care practices, with most of them using herbs/medicinal plants, prayers and blessings that are spread by the community popular tradition by healers, herbalists and religious authorities ("Mothers-of-Saint", lalorixás, pastors, etc.), becoming the main resource against illness and health problems, given the limited access to public health services by the Quilombola population.

In a study carried out with Quilombolas in the state of Santa Catarina, medicinal herbs/plants were also part of the context of the group's social relations, since the cultivation of medicinal plants and herbs took place in the gardens and personal yards, of family members and neighbors and were accessed by the community as a whole, this study also pointed to the existence and knowledge of more than 100 species of medicinal plants used by Quilombolas ${ }^{(36)}$.

It is noticeable that the explanations given for carrying out the health care practices described are anchored in the knowledge that permeates the dimensions of the duty to do, as this practice is developed and passed on from generation to generation by the women of the family and which also highlights the valorization of the traditional knowledge transmitted by them and that configure practices that mark the Quilombola ethnic and racial identity ${ }^{(37)}$. The doing is given through feelings of protection, concern, and love and the doing as prevention or treatment/cure of diseases. Other explanations are anchored in memories of traumatic experiences lived in the hospital environment, by the death/loss of family and loved ones, as well as by the magical explanation, anchored in religious precepts and supported by faith in believing in divine supernatural action and the power of medicinal herbs.

The experience of falling ill can build a personal and particular experience in the subjects, since the disease is also considered to be a phenomenon of a psychobiological and sociocultural nature, which, combined with personal trajectories and experiences, are capable of constituting social representations that are related to social interactions and the care and health practices adopted.

It is worth highlighting that the religious aspect and spirituality can contribute to the knowledge and practices about health care, as they are able to influence behaviors and direct actions in the community, acting as guides, which guide the individual's actions with the world ${ }^{(38)}$. This aspect can be evidenced in this study in the association of care to a biblical commandment, showing that the context of religion guides the practice of care referred by women.

The concepts presented are socially shared in people's daily lives. It became evident that the context of the home, the community itself, religious communities, and the context or contact with health services strongly influence the formation of health care concepts and practices, as these are part of the historical, cultural and social context of Quilombola women.

The Quilombola woman is represented as the caregiver, whose meaning is symbolically constructed as the mainstay of the family. The expression mainstay symbolizes and aims at a set of meanings that express this woman's representation: she supports the family. A mainstay is an object made of wood, iron or metal, often found in houses to support the roof and walls, that is, without the mainstay, the house may collapse. So is the woman caregiver: the one who supports, protects, helps, assists her loved ones, a support on which the family and all its components are based because the existence and maintenance of the family depend on it. This idea was also presented in a study ${ }^{(39)}$ that sought the meaning of the roles of father and mother for couples who went through the experience of parenting, with the woman also being identified as the main caregiver of the home and family, an elementary figure of care, based on the argument that parental ties and affection legitimize her in this role, being held accountable and seen as a central figure in the care of the children and family members.

\section{Study limitations}

Considering that the study was developed in only one Quilombola community, the representations discussed here may not be subject to generalization. Since they concern the universe of the worldview of groups that represent social objects from their practical experiences in daily life, these are particular to each group. However, these findings may contribute to make this universe known and encourage reflection in similar studies in other communities.

\section{Contributions to the Nursing field}

Knowing health care practices and the logic that supports them contributes to broadening the understanding of specific social groups, considering the cultural and representational dimension that care practices acquire in their lives and the universe of representations that permeate them. These aspects must be considered by health professionals and, above all, nurses, since this, in particular, acts and (re)produces comprehensive health care for individuals and their respective groups. Furthermore, given that the figure of the health professional that appears in the speeches of the participants is that of the doctor, it is understood that understanding the representations and, therefore, the health practices of Quilombola women, favor a closer approach for nurses in the organization of care that meets the particularities of these populations.

\section{FINAL CONSIDERATIONS}

Health care practices were characterized by actions related to the home, people, families and the environment indicating that Quilombola women have an expanded understanding of health care, of a preventive nature and not only associated with states of concrete illness. The resources applied in care are natural and come from traditional knowledge, especially through plants and herbs. The official health system is activated in the second instance, with the figure of the doctor being cited when the own resources applied have no effect or when another authority is required, other than that of the main caregiver of the family.

The mother is the main caregiver of the family, with different status in the female universe of the family, as it is not enough to be a woman, it is necessary to be a mother with special attributes that give her a superlative condition in the exercise of care. The supermom is the figure that aggregates the universe of meanings that make health care viable and applicable in daily 
life, therefore, to enter the Quilombola community, health professionals need to understand this representational universe and, through women-mothers-caregivers, to make the official health care system reach this population group.

\section{FUNDING}

Coordination for the Improvement of Higher Education Personnel (CAPES).

\section{REFERENCES}

1. Waldow VR. Enfermagem: a prática do cuidado sob o ponto de vista filosófico. Investig Enferm. Imagen Desarr. 2015;17(1):13-25. doi: 10.11144/Javeriana. IE17-1.epdc

2. Berg JA, Woods NF. Global women's health: a spotlight on caregiving. Nurs Clin N Am. 2009;44(3):375-84. doi: 10.1016/j.cnur.2009.06.003

3. Ferreira CR, Isaac L, Ximenes VS. Cuidar de idosos: um assunto de mulher? Estu. Interdiscip Psicol. 2018;9(1):108-25. doi: 10.5433/2236-6407.2016v9n1p108

4. Waldow VR. Cuidar: expressão humanizadora da enfermagem. 3a ed. Petrópolis, RJ: Vozes; 2010.

5. Ministério da Saúde (BR). Política Nacional de Saúde Integral da População Negra: uma política para o SUS - 2. ed. - Brasília: Ministério da Saúde; 2013.

6. Reis AT, Santos RS, Paschoal Júnior A. O cuidado à mulher na contemporaneidade: reflexões teóricas para o exercício da enfermagem transcultural. Rev Min Enferm [Internet]. 2012 [cited 2019 Jan 20];16(1):129-35. Available from: http://www.reme.org.br/artigo/detalhes/510

7. Prates LA, Ceccon FG, Alves CN, Wilhelm LA, Demori CC, Silva SC, et al. A utilização da técnica de grupo focal: um estudo com mulheres quilombolas. Cad Saúde Pública. 2015;31(12):2483-92. doi: 10.1590/0102-311X00006715

8. Oliveira MW, Moraes JV. Práticas populares de saúde e a saúde da mulher. Rev APS [Internet]. 2010 [cited 2017 Mar 28];13(4):412-20. Available from: https://aps.ufjf.emnuvens.com.br/aps/article/viewFile/723/387

9. Prates LA, Possati AB, Timm MS, Bortoli CFC, Bisognin P, Ressel LB. Características socioeconômicas e de saúde de um grupo de mulheres de uma comunidade quilombola. Rev Enferm UFPE [Internet]. 2016 [cited 2018 Jun 10];10(1):103-11. Available from: https://periodicos.ufpe.br/ revistas/revistaenfermagem/article/download/10927/12216

10. Moscovici S. A Psicanálise, sua imagem e seu público. Petrópolis: Vozes, 2012.

11. Cardoso CS, Melo LO, Freitas DA. Health conditions in quilombola communities. Rev Enferm UFPE. 2018;12(4):1037-45. doi: 10.5205/1981-8963-v12i4a110258p1037-1045-2018

12. Freitas DA, Caballero AD, Marques AS, Hernández CIV, Antunes SLNO. Saúde e comunidades quilombolas: uma revisão da literatura. Rev CEFAC. 2011;13(5):937-43. doi: 10.1590/S1516-18462011005000033

13. Franchi EPLP, Terra MF, Nascimento-Rocha JM, Marquezan RF, Odorizzi VF. A formação de profissionais de saúde no cuidado às comunidades quilombolas: um relato de experiência. Rev Bras Med Fam Comun. 2018;13(40):1-11. doi: 10.5712/rbmfc13(40)1620

14. Tong A, Sainsbury P, Craig J. Consolidated criteria for reporting qualitative research (COREQ): a 32-item checklist for interviews and focus groups. Int J Qual Health Care. 2007;19(6):349-57. doi: 10.1093/intqhc/mzm042

15. Jodelet D. O movimento de retorno ao sujeito e a abordagem das representações sociais. Soc Estado. 2009;24(3):679-712. doi: 10.1590/ S0102-69922009000300004

16. Minayo MCS. Amostragem e saturação em pesquisa qualitativa: consensos e controvérsias. Rev Pesqui Qualit [Internet]. 2017 [cited 2020 Mar 17];5(7):01-12. Available from: https://editora.sepq.org.br/index.php/rpq/article/view/82/59

17. Saunders B, Sim J, Kingstone T, Baker S, Waterfield J, Bartlam B. et al. Saturation in qualitative research: exploring its conceptualization and operationalization. Qual Quant 2018;52(4):1893-907. doi: 10.1007/s11135-017-0574-8

18. Ferreira MA. Teoria das representações sociais e contribuições para as pesquisas do cuidado em saúde e de enfermagem. Esc Anna Nery. 2016;20(2):214-5. doi: 10.5935/1414-8145.20160028

19. Jaccoud M, Mayer R. A observação direta e a pesquisa qualitativa. In: Poupart J. et al. A pesquisa qualitativa: enfoques epistemológicos e metodológicos. 2 ed. Petrópolis, Rio de Janeiro: Vozes, 2010.

20. Bardin L. Análise de Conteúdo. São Paulo: Edições 70, 2011.

21. Silva EB, Menezes LP, Stamm B, Hempel SF, Nora LSD. Saberes e práticas de pais ou responsáveis no cuidado de pré-escolares. Rev Enferm UFSM. 2013;3(2):185-96. doi: 10.5902/217976926282

22. Moreira MA, Nascimento ER, Paiva MS. Social representations concerning the breastfeeding practices of women from three generations. Texto Contexto Enferm. 2013;22(2):432-41. doi: 10.1590/S0104-07072013000200020

23. Vasconcelos MR, Corrêa RS. Impactos socioambientais causados pelo aterro sanitário no município de Marituba-Pa. In: Seminário Nacional de Serviço Social, Trabalho e Política Social n²; Universidade Federal de Santa Catarina (Florianópolis), SC. Anais do Seminário Nacional de Serviço Social, Trabalho e Política Social [Internet]. 2017[cited 2020 Mar 17]. Available from: https://repositorio.ufsc.br/xmlui/ handle/123456789/180039 
24. Oliveira G, Scazufca P, Pires RC. Ranking do saneamento [Internet]. São Paulo: Instituto Trata Brasil; 2018[cited 2020 Mar 17]. Available from: http://www.tratabrasil.org.br/images/estudos/itb/ranking-2018/realatorio-completo.pdf.

25. Freitas IA, Rodrigues ILA, Silva IFS, Nogueira LMV. Perfil sociodemográfico e epidemiológico de uma comunidade quilombola na Amazônia Brasileira. Rev Cuid. 2018;9(2):2187-200. doi: 10.15649/cuidarte.v9i2.521

26. Bezerra VM, Medeiros DS, Gomes KO, Souzas R, Giatti L, Steffens AP, et al . Inquérito de Saúde em Comunidades Quilombolas de Vitória da Conquista, Bahia, Brasil (Projeto COMQUISTA): aspectos metodológicos e análise descritiva. Ciênc Saúde Coletiva. 2014;19(6):1835-47. doi: $10.1590 / 1413-81232014196.01992013$

27. Kochergin CN, Proietti FA, César CC. Comunidades quilombolas de Vitória da Conquista, Bahia, Brasil: autoavaliação de saúde e fatores associados. Cad Saúde Pública. 2014;30(7):1487-501. doi: 10.1590/0102-311X00141213

28. Santos RC, Silva MS. Condições de vida e itinerários terapêuticos de quilombolas de Goiás. Saúde Soc. 2014;23(3):1049-63. doi: 10.1590/ S0104-12902014000300025

29. Rangel DLO, Oliveira C, Kyaw CM, Caldeira Jr AM, Monteiro PS. Perfil parasitológico de moradores de uma comunidade quilombola. Acta Paul Enferm. 2014;27(6):513-9. doi: 10.1590/1982-0194201400084

30. Juras IAGM, Machado GS. A relação entre a saúde da população e a conservação do meio ambiente. In: GANEM RS. (Org.). Políticas setoriais e meio ambiente. Brasília: Câmara dos Deputados, Edições Câmara, 2015. p. 177-210.

31. Medeiros DS, Moura CS, Guimarães MDC, Acurcio FA. Medication use by the "quilombola" population: a survey in Southwestern Bahia, Brazil. Rev Saúde Pública. 2013;47(5):905-13. doi: 10.1590/S0034-8910.2013047004817

32. Araújo MEA, Silva MT, Andrade KRC, Galvão TF, Pereira MG. Prevalence of health services utilization in Brazil: a systematic review and metaanalysis. Epidemiol Serv Saúde. 2017;26(3):589-604. doi: 10.5123/s1679-49742017000300016

33. Raynaudo G, Peralta O. Cambio conceptual: una mirada desde las teorías de Piaget y Vygotsky. Liberabit. 2017;23(1);137-48. doi: 10.24265/ liberabit.2017.v23n1.10

34. Lima ARA, Heck RM, Vasconcelos MKP, Barbieri RL. Actions of women farmers in family care: use of medicinal plants in Southern Brazil. Texto Contexto Enferm. 2014;23(2):365-72. doi: 10.1590/0104-07072014004080012

35. Siqueira SMC, Jesus VS, Camargo CL. The therapeutic itinerary in urgent/emergency pediatric situations in a maroon community. Ciênc Saúde Coletiva. 2016;21(1):179-89. doi: 10.1590/1413-81232015211.20472014

36. Zank S, Ávila JVC, Hanazaki N. Compreendendo a relação entre saúde do ambiente e saúde humana em comunidades Quilombolas de Santa Catarina. Rev Bras Plantas Med. 2016;18(1):157-67. doi: 10.1590/1983-084X/15 142

37. Mendes DS, Cavas CST. Benzedeiras e benzedeiros quilombolas: construindo identidades culturais. Interações. 2018;19(1):3-14. doi: 10.20435/inter.v19i1.1568

38. Borges MS, Santos MBC, Pinheiro TG. Social representations about religion and spirituality. Rev Bras Enferm. 2015;68(4):609-16. doi: 10.1590/0034-7167.2015680406i

39. Martins CA, Abreu WJCP, Figueiredo MCAB. Tornar-se pai e mãe: um papel socialmente construído. Rev Enferm Ref. 2014;serIV(2):121-31.doi: 10.12707/RIII1394 